\title{
Design and synthesis of novel N(4)-substituted thiosemicarbazones bearing a pyrrole unit as potential anticancer agents
}

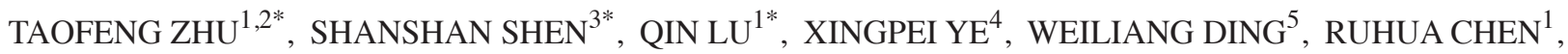 \\ JING XIE ${ }^{6}$, WENJIAO ZHU ${ }^{5}$, JUN XU ${ }^{4}$, LEI JIA ${ }^{4}$, WEINA WU ${ }^{4}$ and TIELIANG MA ${ }^{5}$ \\ ${ }^{1}$ Department of Respiratory Disease, The First Affiliated Hospital of Soochow University, Suzhou, Jiangsu 215006; \\ ${ }^{2}$ Department of Respiratory Disease, The Affiliated Yixing Hospital of Jiangsu University, Yixing, Jiangsu 214200; \\ ${ }^{3}$ Department of Gastroenterology, The Affiliated Drum Tower Hospital of Nanjing University Medical School, \\ Nanjing, Jiangsu 210008; ${ }^{4}$ Department of Physics and Chemistry, College of Chemistry and Chemical Engineering, \\ Henan Polytechnic University, Jiaozuo, Henan 454000; ${ }^{5}$ Central Laboratory; ${ }^{6}$ Department of Geriatrics, \\ The Affiliated Yixing Hospital of Jiangsu University, Yixing, Jiangsu 214200, P.R. China
}

Received June 8, 2015; Accepted February 27, 2017

DOI: $10.3892 / 01.2017 .5995$

\begin{abstract}
A series of N(4)-substituted thiosemicarbazones (TSCs) bearing pyrrole unit (1a-1e) were synthesized and fully characterized by elemental analyses, infrared spectra, ${ }^{1} \mathrm{H}$ nuclear magnetic resonance and single crystal X-ray diffraction. The compounds were assessed as potential chemotherapeutic agents. All newly synthesized compounds were screened for their anticancer activity against lung cancer PC-9, esophageal cancer Eca-109 and gastric cancer SGC-7901 cell lines. The results of MTT, Terminal deoxynucleotidyl transferase dUTP nick end labeling and fluorescence-activated cell sorting assays indicated that all the prepared compounds exhibited cytotoxicity against PC-9, Eca-109 and SGC-7901 cells in vitro. All the compounds significantly induced cancer cell apoptosis accompanied by increasing the Bax/Bcl-2 ratio and activation of caspase- 3 . The structure-activity association was discussed and the potential pre-clinical trials may be conducted. The present findings have a great potential in biomedical applications of novel N(4)-substituted TSCs.
\end{abstract}

Correspondence to: Dr Tieliang Ma, Central Laboratory, The Affiliated Yixing Hospital of Jiangsu University, 75 Tongzhenguan Road, Yixing, Jiangsu 214200, P.R. China

E-mail: matieliang@foxmail.com

Dr Weina Wu, Department of Physics and Chemistry, College of Chemistry and Chemical Engineering, Henan Polytechnic University, 2001 Shiji Street, Jiaozuo, Henan 454000, P.R. China

E-mail:wuwn08@hpu.edu.cn

*Contributed equally

Key words: thiosemicarbazone, pyrrole, cytotoxic

\section{Introduction}

In previous decades, thiosemicarbazones (TSCs) have been a focus of chemists and biologists due to their wide range of pharmacological effects, such as antibacterial, antiviral, antifungal, and antitumor activity (1-3). Among TSCs, (N)-heterocyclic TSCs have been extensively investigated as potential anticancer agents, and 3-aminopyridine-2-carboxaldehyde TSC (3-AP or triapine) is currently undergoing phase II clinical trials (4). It has been confirmed that TSCs play essential antitumor roles through numerous mechanisms, including ribonucleotide reductase inhibition $(5,6)$, metal-dependent radical damage (4), DNA binding (7) and inhibition of protein synthesis (8). However, it should be noted that the biological activities of TSCs often show a high dependence on their substituents $(1,4)$. Therefore, there is increasing interest in structural modification of TSC derivatives, with the aim of improving the pharmaceutical profile of existing candidates or identifying novel derivatives. At present, the majority of studies have focused on the structure-activity association of TSCs bearing six-member heterocycles (9-14). However, the antitumor effects and the underlying mechanisms of TSCs containing five-member heterocycles (15), particularly pyrrole, remain poorly understood. It is well known that a large amount of pyrrole constitutes, such as sunitinib, are a class of promising anticancer agents (16). Our previous work has also shown that certain acylhydrazones bearing a pyrrole unit have antitumor activity towards hepatocellular carcinoma HepG2 cells (17). In addition, certain pyrrole imines can bind to DNA effectively (18). Therefore, a series of TSCs derived from formyl-pyrrole were synthesized in the present study.

\section{Materials and methods}

Reagents. Ethyl-5-formyl-1H-pyrrole-2-carboxylate, 4-substituted thiosemicarbazide, ethanol and methanol were purchased from Beijing Chemical Works (Beijing, China). Elemental analyses (concentration of each compound, $1.25 \times 10^{-5} \mathrm{~mol} / \mathrm{l}$ ) 
were performed at the Microanalytical Laboratory of the Department of Chemistry of Lanzhou University (Lanzhou, China) using the CHN-O-Rapid analyzer (Foss Heraeus GmbH, Hanau, Germany). ${ }^{1} \mathrm{H}$ nuclear magnetic resonance (NMR) spectra were recorded on a Bruker AV400 NMR spectrometer (Bruker Corporation, Billerica, MA, USA) in $d_{6}$-dimethyl sulfoxide (DMSO) solution, with tetramethylsilane as an internal standard. The infrared (IR) spectra $\left(v=4,000-400 \mathrm{~cm}^{-1}\right)$ were determined by the $\mathrm{KBr}$ pressed disc method on a Bruker V70 FT-IR (Bruker Corporation) spectrophotometer. The single crystal X-ray diffraction measurements for $1 \mathrm{a} \cdot \mathrm{CH}_{3} \mathrm{OH}$, $1 \mathrm{~b}$ and $1 \mathrm{e}$ were determined on a Bruker SMART APEX IICCD diffractometer (Bruker Corporation) equipped with a

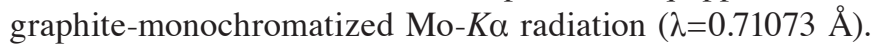
Semi-empirical absorption correction was applied to the intensity data using the SADABS program (19). The structures were solved by direct methods and refined by full matrix least-square on $F^{2}$ using the SHELXTL-97 program (20). All non-hydrogen atoms were refined anisotropically. All $\mathrm{H}$ atoms were positioned geometrically and refined using a riding model.

General synthesis procedure of TSCs la-e. Ethyl 5 -formyl-1H-pyrrole-2-carboxylate $(0.167 \mathrm{~g}, 1 \mathrm{mmol})$ and differently 4-substituted thiosemicarbazide (1 mmol) were mixed in ethanol $(5 \mathrm{ml})$. Subsequent to $0.05 \mathrm{ml}$ of acetic acid being added, the resultant mixture was kept refluxing for $\sim 4 \mathrm{~h}$. The progress of the reaction was monitored by thin layer chromatography. Following completion of the reaction, the separated solid was filtered and recrystallized in methanol. The single crystals suitable for X-ray diffraction measurements were obtained during the recrystallization process.

1a: Yellow powder. Yield 66\%. Melting point (M.p.) $205-208^{\circ} \mathrm{C}$. IR $\left(\max , \mathrm{cm}^{-1}\right): 1,683(\mathrm{C}=\mathrm{O}) ; 1,594(\mathrm{C}=\mathrm{N})$; and $760(\mathrm{C}=\mathrm{S}) .{ }^{1} \mathrm{H}$ NMR $\left(400 \mathrm{MHz}, d_{6}\right.$-DMSO, ppm): 1.22-1.25 (t, 3H, 8'- $\left.\mathrm{CH}_{3}, \mathrm{~J}=8.0 \mathrm{~Hz}\right)$; 4.19-4.25 (q, 2H, 7'- $\mathrm{CH}_{2}, \mathrm{~J}=8.0 \mathrm{~Hz}$ ); 6.46-6.48 (q, 1H, 3'-CH, J=4.0 Hz); 6.73-6.75 (q, 1H, 4'-CH, $\mathrm{J}=4.0 \mathrm{~Hz}) ; 7.80$ (s, 1H, 1'-CH); 8.19 (s, 1H, 4-NH); 8.39-8.40 (d, 1H, 4-NH); 11.42 (s, 1H, pyrrole-NH); and 12.09 (s, 1H, 2-NH). Analysis calculated for $\mathrm{C}_{9} \mathrm{H}_{12} \mathrm{~N}_{4} \mathrm{O}_{2} \mathrm{~S}: \mathrm{C}, 44.99 \% ; \mathrm{H}$, 5.03\%; and N, 23.32\%; found: C, 45.12\%; H, 5.13\%; and N, $23.47 \%$.

1b: Yellow powder. Yield $75 \%$. M.p. $220-221^{\circ} \mathrm{C}$. IR $\left(\max , \mathrm{cm}^{-1}\right): 1,705(\mathrm{C}=\mathrm{O}) ; 1,616(\mathrm{C}=\mathrm{N})$; and $754(\mathrm{C}=\mathrm{S}) .{ }^{1} \mathrm{H}$ NMR (400 MHz, $d_{6}$-DMSO, ppm): 1.22-1.26 (t, 3H, 8'- $\mathrm{CH}_{3}$, $\mathrm{J}=8.0 \mathrm{~Hz}) ; 3.00-3.01\left(\mathrm{t}, 3 \mathrm{H}, 4-\mathrm{CH}_{3}\right) ; 4.20-4.26\left(\mathrm{q}, 2 \mathrm{H}, \mathbf{7}^{\prime}-\mathrm{CH}_{2}\right.$, $\mathrm{J}=8.0 \mathrm{~Hz}) ; 6.49-6.50\left(\mathrm{q}, 1 \mathrm{H}, 3^{\prime}-\mathrm{CH}, \mathrm{J}=4.0 \mathrm{~Hz}\right) ; 6.75-6.76(\mathrm{q}$, $\left.1 \mathrm{H}, 4^{\prime}-\mathrm{CH}, \mathrm{J}=4.0 \mathrm{~Hz}\right) ; 7.82$ (s, 1H, 1'-CH); 8.73-8.77 (q, 1H, 4-NH); 11.50 (s, 1H, pyrrole-NH); and 11.95 (s, 1H, 2-NH). Analysis calculated for $\mathrm{C}_{10} \mathrm{H}_{14} \mathrm{~N}_{4} \mathrm{O}_{2} \mathrm{~S}$ : C, 47.23\%; $\mathrm{H}, 5.55 \%$; and N, 22.03\%; found: C, 46.99\%; H, 5.42\%; and N, $22.15 \%$.

1c: Yellow powder. Yield $77 \%$. M.p. $206-208^{\circ} \mathrm{C}$. IR (max, $\left.\mathrm{cm}^{-1}\right): 1,680[\mathrm{C}=\mathrm{O}$ stretching (str.)]; 1,611 (C=N str.); and 763 $(\mathrm{C}=\mathrm{S}) .{ }^{1} \mathrm{H}$ NMR $\left(400 \mathrm{MHz} ; d_{6}\right.$-DMSO, ppm): 1.10-1.14 (t, $\left.3 \mathrm{H}, 4-\mathrm{CH}_{3}, \mathrm{~J}=8.0 \mathrm{~Hz}\right) ; 1.22-1.26\left(\mathrm{t}, 3 \mathrm{H}, 8^{\prime}-\mathrm{CH}_{3}, \mathrm{~J}=8.0 \mathrm{~Hz}\right)$; 3.53-3.60 (m, 4H, 4- $\left.\mathrm{CH}_{2}\right)$; 4.20-4.26 (q, 2H, 7'- $\mathrm{CH}_{2}, \mathrm{~J}=8.0 \mathrm{~Hz}$ ); 6.50-6.51 (q, 1H, 3'-CH, J=4.0 Hz); 6.75-6.77 (q, 1H, 4'-CH, $\mathrm{J}=4.0 \mathrm{~Hz}) ; 7.83$ (s, 1H, 1'-CH); 8.77-8.80 (t, 1H, 4-NH); 11.44 (s, 1H, pyrrole-NH); and 11.94 (s, 1H, 2-NH). Analysis calculated for $\mathrm{C}_{11} \mathrm{H}_{16} \mathrm{~N}_{4} \mathrm{O}_{2} \mathrm{~S}$ : C, 49.24\%; $\mathrm{H}, 6.01 \%$; and $\mathrm{N}, 20.88 \%$; found: C, $49.30 \%$; H, 5.92\%; and N, 20.95\%. 1d: Yellow powder. Yield 63\%. M.p. $167-169^{\circ} \mathrm{C}$. IR (max, $\left.\mathrm{cm}^{-1}\right): 1,673(\mathrm{C}=\mathrm{O}) ; 1,615(\mathrm{C}=\mathrm{N})$; and $757(\mathrm{C}=\mathrm{S}) .{ }^{1} \mathrm{H}$ NMR (400 MHz; $d_{6}$-DMSO, ppm): 1.18-1.20 (d, 6H, 4- $\mathrm{CH}_{3}$, $\mathrm{J}=8.0 \mathrm{~Hz}) ; 1.23-1.26$ (t, 3H, 8'- $\left.\mathrm{CH}_{3}, \mathrm{~J}=8.0 \mathrm{~Hz}\right) ; 4.20-4.25$ (q, $\left.2 \mathrm{H}, 7^{\prime}-\mathrm{CH}_{2}, \mathrm{~J}=8.0 \mathrm{~Hz}\right)$; 4.44-4.53 (m, 1H, 4-CH); 6.52-6.53 (q, 1H, 3'-CH, J=4.0 Hz); 6.76-6.78 (q, 1H, 4'-CH, J=4.0 Hz); 7.85 (s, 1H, 1'-CH); 8.24-8.26 (d, 1H, 4-NH); 11.40 (s, 1H, pyrrole-NH); and 11.98 (s, 1H, 2-NH). Analysis calculated for $\mathrm{C}_{12} \mathrm{H}_{18} \mathrm{~N}_{4} \mathrm{O}_{2} \mathrm{~S}$ : C, 51.04\%; H, 6.43\%; and N, 19.84\%; found: C, $50.89 \%$; H, 6.52\%; and N, $19.73 \%$.

1e: Yellow powder. Yield $58 \%$. M.p. $195-197^{\circ} \mathrm{C}$. IR (max, $\left.\mathrm{cm}^{-1}\right): 1,675(\mathrm{C}=\mathrm{O}) ; 1,598(\mathrm{C}=\mathrm{N})$; and $764(\mathrm{C}=\mathrm{S}) .{ }^{1} \mathrm{H}$ NMR (400 MHz; $d_{6}$-DMSO, ppm): 1.22-1.26 (t, 3H, 8'- $\mathrm{CH}_{3}$, $\mathrm{J}=8.0 \mathrm{~Hz}) ; 4.20-4.26$ (q, 2H, 7'- $\left.\mathrm{CH}_{2}, \mathrm{~J}=8.0 \mathrm{~Hz}\right) ; 6.56-6.58$ (q, 1H, 3'-CH, J=4.0 Hz); 6.77-6.79 (q, 1H, 4'-CH, J=4.0 Hz), 7.37-7.50 (m, 5H, 4-phenyl); 7.93 (s, 1H, 1'-CH); 10.31 (s, 1H, 4-NH); 11.85 (s, 1H, pyrrole-NH); and 12.11 (s, 1H, 2-NH). Analysis calculated for $\mathrm{C}_{15} \mathrm{H}_{16} \mathrm{~N}_{4} \mathrm{O}_{2} \mathrm{~S}$ : C, 56.94\%; $\mathrm{H}, 5.10 \%$; and N, $17.71 \%$; found: C, $56.85 \%$; H, 5.21\%; and N, $17.68 \%$.

Cell culture. The human non-small cell lung adenocarcinoma PC-9, esophageal squamous carcinoma Eca-109 and gastric adenocarcinoma SGC-7901 cell lines were obtained from the Cell Culture Center of the Basic Institute of Medical Sciences, Peking Union Medical College (Beijing, China), and were routinely maintained at Central Laboratory of the Affiliated Yixing Hospital of Jiangsu University (Yixing, China). All three cell lines were cultured in RPMI-1640 medium containing $10 \%$ fetal calf serum. Cell culture reagents were purchased from Gibco (Thermo Fisher Scientific, Inc., Waltham, MA, USA). All cells were maintained in a humidified incubator at $37^{\circ} \mathrm{C}$ with a $5 \% \mathrm{CO}_{2}$ atmosphere.

MTT assay. MTT assay was applied to evaluate the potential anticancer abilities of TSCs 1a-e. MTT assay kits were purchased from Beyotime Institute of Biotechnology (Haimen, China). Briefly, the three tumor cell lines (PC-9, Eca-109 and SGC-7901) were plated in 96-well plates in triplicate at a density of at $1 \times 10^{4}$ cells/well and grown to $75 \%$ confluency. Subsequent to treatment with $1-2,500 \mu \mathrm{M}$ concentrations of the TSCs for $72 \mathrm{~h}$, the media were replaced with $10 \mu \mathrm{l}$ of fresh media containing $0.45 \mathrm{mg} / \mathrm{ml}$ MTT reagent. The cells were incubated for $1 \mathrm{~h}$ at $37^{\circ} \mathrm{C}$ in a $5 \% \mathrm{CO}_{2}$ atmosphere to allow for formation of formazan crystals. The formazan crystals were dissolved by addition of $100 \mu \mathrm{l}$ DMSO during a 4-h incubation at $37^{\circ} \mathrm{C}$ and $5 \% \mathrm{CO}_{2}$. Colorimetric change was measured on a spectrophotometer at an absorbance of $570 \mathrm{~nm}$. Data was expressed as percentage viability relative to vehicle. At least three independent experiments were performed.

Terminal dexynucleotidyl transferase (TdT)-mediated dUTP nick end labeling (TUNEL) staining. TUNEL assay kits were purchased from Kaiji BioTech (Nanjing, China), and TUNEL staining was applied according to the manufacturer's protocol. Briefly, the PC-9, Eca-109 and SGC-7901 cells (3x10 $)$ were seeded into 24 -well plates and incubated overnight at $37^{\circ} \mathrm{C}$ in a humidified atmosphere containing $5 \% \mathrm{CO}_{2}$. The cells were treated by the TSCs with each corresponding $\mathrm{IC}_{25}$ dose for $24 \mathrm{~h}$. Cells were fixed in $4 \%$ formaldehyde for $20 \mathrm{~min}$ at room temperature $\left(15-25^{\circ} \mathrm{C}\right)$ and then rinsed with PBS for $30 \mathrm{~min}$. 
Table I. Crystal data and structure refinements for $1 \mathrm{a} \cdot \mathrm{CH}_{3} \mathrm{OH}, 1 \mathrm{~b}$ and $1 \mathrm{e}$.

\begin{tabular}{|c|c|c|c|}
\hline Data & $1 \mathrm{a} \cdot \mathrm{CH}_{3} \mathrm{OH}$ & $1 b$ & $1 \mathrm{e}$ \\
\hline Empirical formula & $\mathrm{C}_{10} \mathrm{H}_{16} \mathrm{~N}_{4} \mathrm{O}_{3} \mathrm{~S}$ & $\mathrm{C}_{10} \mathrm{H}_{14} \mathrm{~N}_{4} \mathrm{O}_{2} \mathrm{~S}$ & $\mathrm{C}_{15} \mathrm{H}_{16} \mathrm{~N}_{4} \mathrm{O}_{2} \mathrm{~S}$ \\
\hline Formula weight & 272.33 & 7352.74 & 7355.96 \\
\hline $\mathrm{T}(\mathrm{K})$ & $296(2)$ & $296(2)$ & $296(2)$ \\
\hline Space group & Monoclinic & Monoclinic & Triclinic \\
\hline Crystal system & $\mathrm{P} 2(1) / \mathrm{c}$ & $\mathrm{C} 2 / \mathrm{c}$ & $\mathrm{P}-1$ \\
\hline $\mathrm{a}, \AA$ & $6.564(4)$ & $13.6777(13)$ & $13.8242(19)$ \\
\hline $\mathrm{b}, \AA$ & 23.947 (15) & $8.1410(7)$ & $15.147(2)$ \\
\hline $\mathrm{c}, \AA$ & $9.555(6)$ & $23.051(2)$ & $16.839(2)$ \\
\hline$\alpha, \operatorname{deg}$ & 90 & 90 & $110.226(3)$ \\
\hline$\beta, \operatorname{deg}$ & $104.980(12)$ & $106.930(2)$ & $104.337(3)$ \\
\hline$\gamma, \operatorname{deg}$ & 90 & 90 & $90.795(3)$ \\
\hline $\mathrm{V} / \AA^{3}$ & $1450.9(15)$ & $2455.5(4)$ & $3186.3(8)$ \\
\hline Z & 4 & 8 & 8 \\
\hline $\mathrm{Dc}, \mathrm{g} \mathrm{cm}^{-3}$ & 1.247 & 1.376 & 1.319 \\
\hline$\mu, \mathrm{mm}^{-1}$ & 0.230 & 0.260 & 0.215 \\
\hline Size, mm & $0.20 \times 0.16 \times 0.15$ & $0.32 \times 0.25 \times 0.20$ & $0.25 \times 0.20 \times 0.07$ \\
\hline $\mathrm{F}(000)$ & 576 & 1072 & 1328 \\
\hline \multicolumn{4}{|l|}{ Limiting indices } \\
\hline$h$ & $-7 \leq h \leq 6$ & $-11 \leq h \leq 16$ & $-16 \leq h \leq 13$ \\
\hline$k$ & $-28 \leq k \leq 28$ & $-9 \leq k \leq 9$ & $-14 \leq k \leq 18$ \\
\hline$l$ & $-11 \leq l \leq 10$ & $-27 \leq l \leq 18$ & $-19 \leq l \leq 20$ \\
\hline$\theta$ for data collection, deg & $1.70-25.00$ & $1.85-24.99$ & $1.44-25.00$ \\
\hline reflns collected/unique & $6886 / 2503$ & $6071 / 2169$ & $16426 / 11148$ \\
\hline$R_{\text {(int) }}$ & 0.0689 & 0.0276 & 0.0485 \\
\hline Goodness-of-fit on $\mathrm{F}^{2}$ & 1.027 & 1.047 & 1.030 \\
\hline final $R$ indices & $R_{1}=0.0584$ & $R_{1}=0.0346$ & $R_{1}=0.0590$ \\
\hline$[\mathrm{I}>2 \sigma(\mathrm{I})]$ & $w R_{2}=0.1487$ & $w R_{2}=0.0819$ & $w R_{2}=0.0825$ \\
\hline $\mathrm{R}$ indices & $R_{1}=0.1192$ & $R_{1}=0.0462$ & $R_{1}=0.1102$ \\
\hline (all data) & $w R_{2}=0.1897$ & $w R_{2}=0.0888$ & $w R_{2}=0.1698$ \\
\hline Largest peak and hole/e $\AA^{-3}$ & 0.313 and -0.354 & 0.152 and -0.189 & 0.269 and -0.216 \\
\hline
\end{tabular}

Subsequently, the cells were incubated with $3 \%$ hydrogen peroxide in methanol for $10 \mathrm{~min}$ at room temperature followed by washing twice with PBS for $25 \mathrm{~min}$. The TSCs were incubated with $0.1 \%$ Triton $\mathrm{X}-100$ and $0.1 \%$ sodium citrate (Shanghai Shenggong Co., Ltd., Shanghai, China) in water for $30 \mathrm{~min}$ at room temperature. For the negative control, TdT was not added to the sample, and for the positive control, cells were treated with DNase I (Tiangen Biotech Co., Ltd., Beijing, China). Subsequent to washing twice with PBS, pretreated specimens were incubated with $50 \mu \mathrm{l}$ TdT labeling reaction buffer at $4^{\circ} \mathrm{C}$ overnight in dark and then in a humidified atmosphere at $37^{\circ} \mathrm{C}$ for another $2-3 \mathrm{~h}$. Subsequently, the slides were incubated with $50 \mu \mathrm{l}$ streptavidin-HRP for $60 \mathrm{~min}$, followed by detection with $50 \mu \mathrm{l}$ diaminobenzidine reagent for $10 \mathrm{~min}$. The cells seeded were observed at x400 magnification, and images were captured under an optical microscope. The cells stained brown were TUNEL positive, and therefore showed apoptotic characteristics.

Western blot analysis. The PC-9, Eca-109 and SGC-7901 cell lines were seeded into 6-well plates at a density of $1 \times 10^{6}$ cells/well and incubated overnight at $37^{\circ} \mathrm{C}$ in a humidified atmosphere containing $5 \% \mathrm{CO}_{2}$. Cells were treated by the TSCs with each corresponding half maximal inhibitory concentration $\left(\mathrm{IC}_{50}\right)$ dose for $24 \mathrm{~h}$. Following treatment, all the cell samples were washed twice with PBS and lysed in sample buffer. The protein concentration of each sample was determined by bicinchoninic acid protein assay with a commercial kit (cat no. P0009; Beyotime Institute of Biotechnology). The samples were separated by SDS-PAGE, transferred to polyvinylidene fluoride membranes by electroblotting, blocked using $5 \%$ dried skimmed milk overnight at $4^{\circ} \mathrm{C}$, and probed overnight 


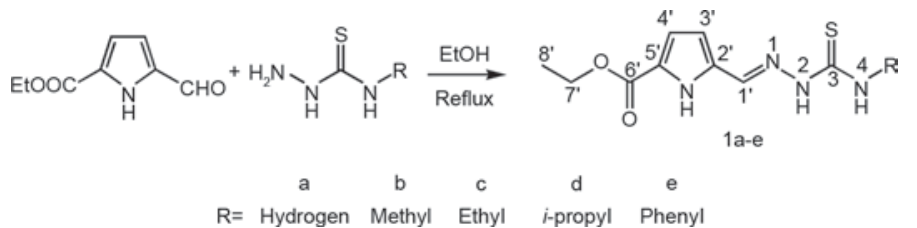

Figure 1. Reaction scheme for the synthesis of thiosemicarbazones 1a-e.

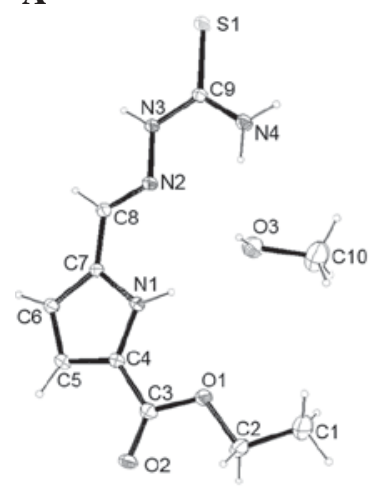

B

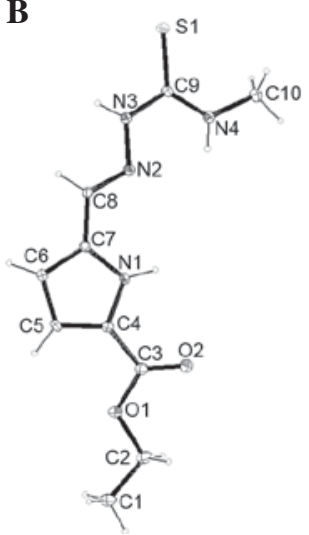

$\mathbf{C}$

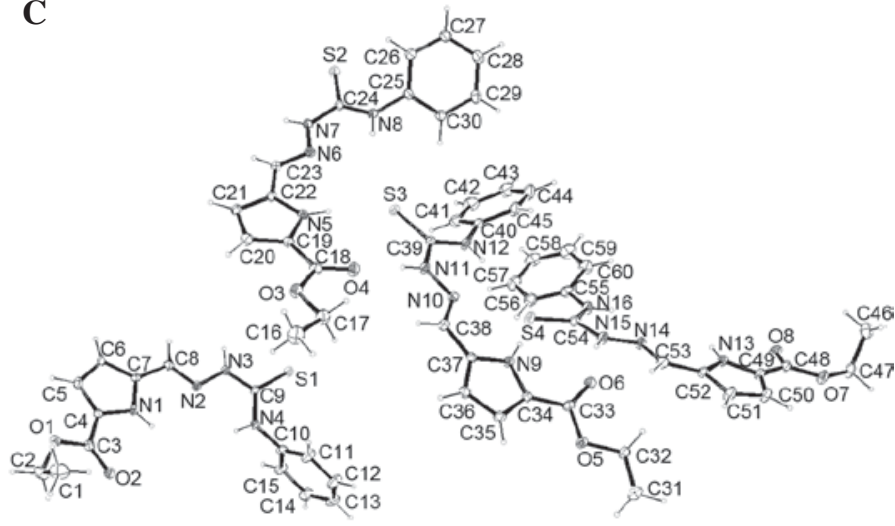

Figure 2. Molecular structures of (A) $1 \mathrm{a} \cdot \mathrm{CH}_{3} \mathrm{OH}$, (B) $1 \mathrm{~b}$ and (C) 1e shown with $10 \%$ probability displacement ellipsoids and atomic numbering scheme.

at $4^{\circ} \mathrm{C}$ with primary antibodies against caspase-3, Bax, Bcl-2 and GAPDH, whcih were diluted 1:1,000, 1:1,000, 1:1,000 and $1: 2,000$, respectively, in $5 \%$ bovine serum albumin (cat. no. 10711454001; Roche Applied Science, Penzberg, Germany). Polyclonal antibodies against caspase-3 (cat. no. 3004), and the apoptosis regulators Bax (cat. no. 3032) and Bcl-2 (cat. no. 3195) were obtained from BioVision, Inc. (Milpitas, CA, USA). Anti-GAPDH (cat. no. E7EUT5) polyclonal antibody was purchased from Abmart, Inc. (Shanghai, China). The membranes were incubated with secondary immunoglublin $G$ (IgG) antibodies conjugated to alkaline phosphatase (AP) for $2 \mathrm{~h}$ at room temperature, followed by two washes with PBS, incubation with an enhanced chemiluminescence reagent (Lumi Phos $^{\text {TM }}$ WB; Thermo Fisher Scientific, Inc.) and visualization on autoradiography film. The AP-conjugated anti-mouse IgG (cat. no. A0258) and AP-conjugated anti-rabbit IgG (cat. no. A0239) secondary antibodies were obtained from Beyotime Institute of Biotechnology and were diluted 1:1,000 in PBS. Densitometry values were determined using UN-SCAN-IT software version 6.0 (Silk Scientific, Inc., Orem, UT, USA) in a ScanJet G4010 flatbed scanner (HP, Inc., Palo Alto, CA, USA).

Statistical analysis. All data were analyzed by SAS 6.12 software (SAS Institute, Cary, NC, USA) and the results were expressed as the mean \pm standard deviation. To compare the differences between the groups, statistical significance was analyzed using a one-way analysis of variance followed by post-hoc comparisons. $\mathrm{P}<0.05$ was considered to indicate a statistically significant difference.

\section{Results}

Synthesis. The TSCs 1a-e were synthesized by the condensation of formyl-1H-pyrrole and 4-substituted thiosemicarbazide in moderate yield. The reaction scheme is shown in Fig. 1. All TSCs were soluble in ethanol, methanol, acetonitrile and chloroform, in addition to DMSO and DMF, but the TSCs were insoluble in water and ethyl ether. The analytical data for $\mathrm{C}, \mathrm{H}$ and $\mathrm{N}$ confirmed the composition of the TSCs and the stoichiometry proposed. Furthermore, all TSCs have similar IR spectra. The strong bands at $\sim 1,680 \mathrm{~cm}^{-1}$ are attributable to stretch vibrations of the carbonyl group $[v(\mathrm{C}=\mathrm{O})](17)$. The peak at $\sim 1610 \mathrm{~cm}^{-1}$ should be assigned to the $v(\mathrm{C}=\mathrm{N})$, and the peak at $\sim 760 \mathrm{~cm}^{-1}$ to $v(\mathrm{C}=\mathrm{S})(15)$.

Single crystal X-ray diffraction was found to be particularly informative in identifying the compound structure. Details of the crystal parameters, data collection and refinements for $1 \mathrm{a} \cdot \mathrm{CH}_{3} \mathrm{OH}, 1 \mathrm{~b}$ and $1 \mathrm{e}$ are summarized in Table I, selected bond lengths and angles are provided in Table II. Fig. 2 shows perspective views of $1 \mathrm{a} \cdot \mathrm{CH}_{3} \mathrm{OH}, 1 \mathrm{~b}$ and $1 \mathrm{e}$. Different from $1 \mathrm{a} \cdot \mathrm{CH}_{3} \mathrm{OH}$ and $\mathrm{lb}$, there are four independent TSCs molecules in the asymmetric unit of 1e. The bond distances are extremely similar in all structures. The S-C bond varies between 1.666 (4) and 1.6907 (19) $\AA$, confirming that each TSC molecule is in a ketone form (15). The imine $\mathrm{C}=\mathrm{N}$ double bond in each structure has an E configuration. The $\mathrm{N}-\mathrm{C}=\mathrm{S}$ and $\mathrm{CH}=\mathrm{N}-\mathrm{N}$ bond lengths are in the ranges of 1.328 (4)-1.352 (4) $\AA$ and 1.273 (4)-1.286 (4) $\AA$, respectively, which are in agreement with other previously known TSCs in the literature $(15,21)$. The Cambridge Crystallographic Data Centre serial numbers for each crystal were as follows: $1032751,1 \mathrm{a} \cdot \mathrm{CH}_{3} \mathrm{OH}$; 1032752 , 1b; and 1032753, 1e.

Cytotoxic activity. The effect of TSCs on the proliferation of tumor cells was explored by MTT assay. The three tumor cells were incubated with five TSCs in RPMI-1640 at a concentration of $0-2,500 \mu \mathrm{M}$, and the cell viability was assessed with MTT assay at $24 \mathrm{~h}$. It was demonstrated that 

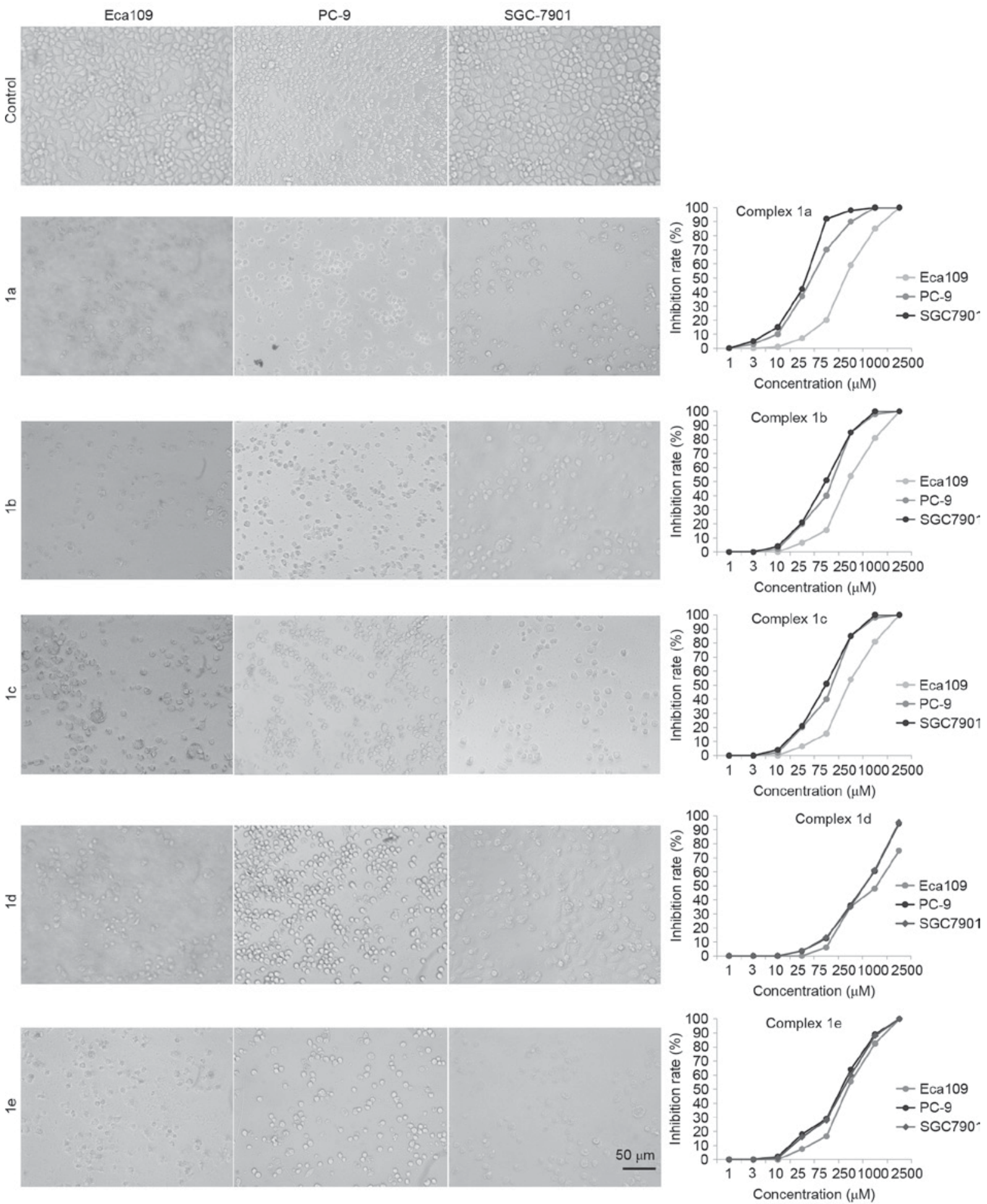

Figure 3. Phase-contrast micrographs of cells treated with the thiosemicarbazone compounds 1a-e.

the five TSCs exhibited a concentration-dependent cytotoxic profile in all three cancer cell lines. $\mathrm{The} \mathrm{IC}_{50}$ values obtained for all tested TSCs are presented in Table III. The morphological examination also showed that the proliferation of the cells was significantly inhibited, and the cells exhibited morphological change, such as cell shrinkage and cell detachment (Fig. 3). The $\mathrm{IC}_{50}$ values for each TSC on all the cells were statistically different and TSCs exhibited a greater effect against SGC-7901 cell lines, indicating that the TSCs bearing pyrrole units may be more effective on the SGC-7901 cell line. In addition, 1a shows the best cytotoxic activity in all tested cell lines among the five tested TSCs, suggesting that 1a may have more significant cytotoxic activities than that of other TSCs.

Cell apoptosis. The cell apoptosis induced by TSCs in the three tumor cell lines was analyzed by TUNEL staining. As shown in Fig. 4, among the five TSCs candidates, 1a shows 
Table II. Selected bond lengths in $1 \mathrm{a} \cdot \mathrm{CH}_{3} \mathrm{OH}, 1 \mathrm{~b}$ and $1 \mathrm{e}$.

\section{$\mathrm{A}, 1 \mathrm{a} \cdot \mathrm{CH}_{3} \mathrm{OH}$}

\begin{tabular}{lc}
\hline Bond & Bond length, $\AA$ \\
\hline $\mathrm{S}(1)-\mathrm{C}(9)$ & $1.696(4)$ \\
$\mathrm{N}(3)-\mathrm{C}(9)$ & $1.343(4)$ \\
$\mathrm{N}(2)-\mathrm{C}(8)$ & $1.273(4)$ \\
\hline
\end{tabular}

$\mathrm{B}, 1 \mathrm{~b}$

\begin{tabular}{lc}
\hline Bond & Bond length, $\AA$ \\
\hline $\mathrm{S}(1)-\mathrm{C}(9)$ & $1.691(19)$ \\
$\mathrm{N}(3)-\mathrm{C}(9)$ & $1.347(2)$ \\
$\mathrm{N}(2)-\mathrm{C}(8)$ & $1.278(2)$ \\
\hline $\mathrm{C}, 1 \mathrm{e}$ & \\
\hline
\end{tabular}

Bond

$\mathrm{S}(1)-\mathrm{C}(9)$

Bond length, $\AA$

$\mathrm{N}(3)-\mathrm{C}(9)$

$1.665(4)$

$\mathrm{N}(2)-\mathrm{C}(8)$

$1.352(4)$

$\mathrm{S}(2)-\mathrm{C}(24)$

$1.286(4)$

$\mathrm{N}(7)-\mathrm{C}(24)$

$1.677(4)$

$1.345(4)$

$\mathrm{N}(6)-\mathrm{C}(23)$

$1.285(4)$

$\mathrm{S}(3)-\mathrm{C}(39)$

$1.675(4)$

$\mathrm{N}(12)-\mathrm{C}(39)$

$1.328(4)$

$\mathrm{N}(10)-\mathrm{C}(38)$

$1.277(4)$

$\mathrm{S}(4)-\mathrm{C}(54)$

$1.666(4)$

$\mathrm{N}(16)-\mathrm{C}(54)$

$1.339(5)$

$\mathrm{N}(14)-\mathrm{C}(53)$

$1.273(5)$

Table III. $\mathrm{IC}_{50}$ values of compoundes 1a-e against the three human cancer cell lines subsequent to incubation for $72 \mathrm{~h}$.

\begin{tabular}{lrrr}
\hline & \multicolumn{3}{c}{$\mathrm{IC}_{50}, \mu \mathrm{mol} / \mathrm{l}$} \\
\cline { 2 - 4 } $\begin{array}{l}\text { Tested } \\
\text { compounds }\end{array}$ & PC-9 & Eca109 & SGC-7901 \\
\hline 1a & 44.87 & 157.75 & 33.52 \\
1b & 102.08 & 250.60 & 73.88 \\
1c & 424.78 & 660.84 & 36.60 \\
1d & 469.39 & $1,082.89$ & 460.41 \\
1e & 131.65 & 228.28 & 141.04
\end{tabular}

$\mathrm{IC}_{50}$, half maximal inhibitory concentration.

the strongest induction of tumor cell apoptosis among the five TSCs, corresponding to its cytotoxic activity.

Changes in Bax, Bcl-2 and caspase-3 protein levels in cancer cells. In order to explore the potential mechanisms of the

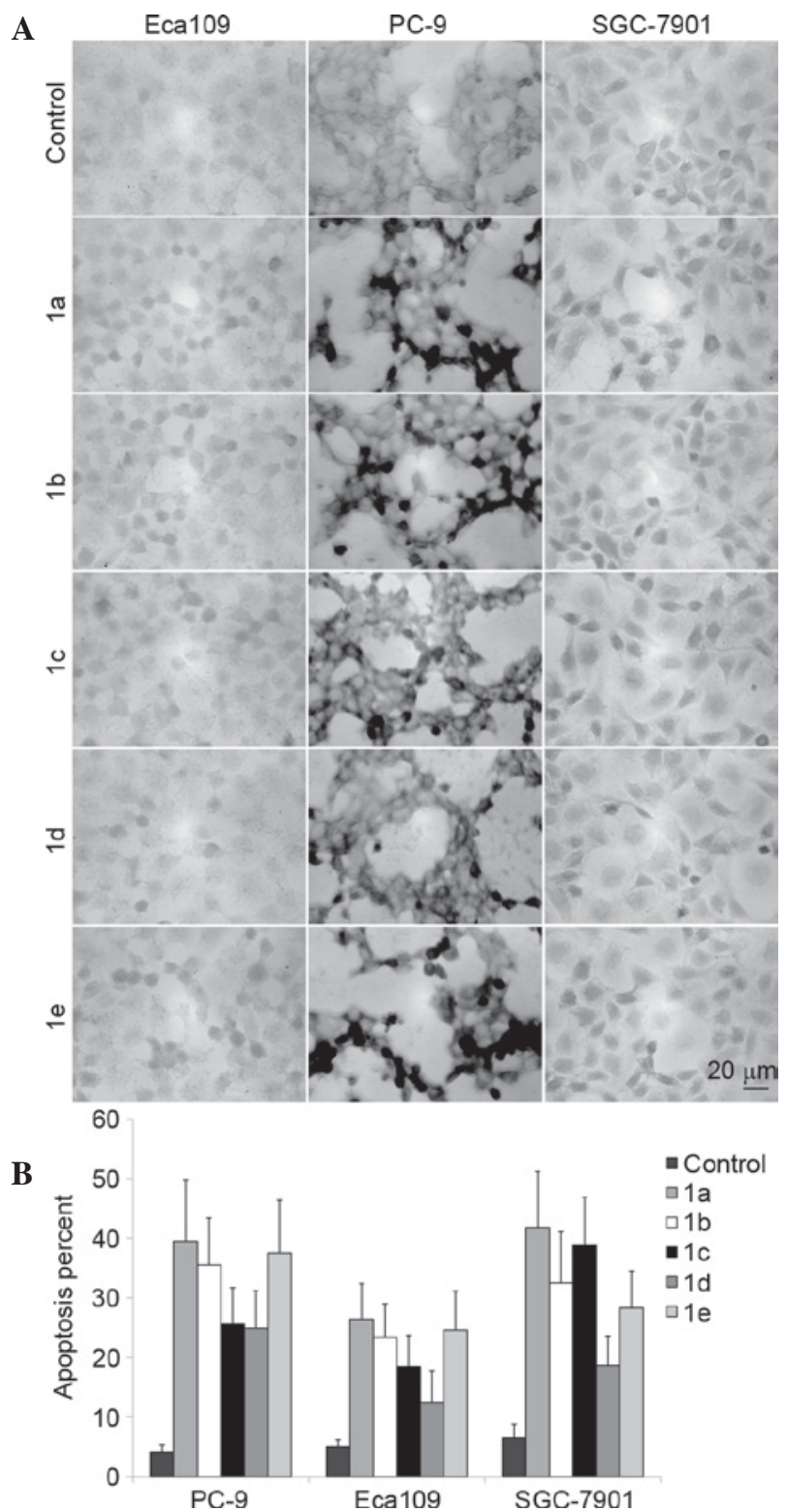

Figure 4. (A) Apoptosis in the three cancer cells treated with thiosemicarbazones. (B) Apoptosis percentage of the three cancer cell lines.
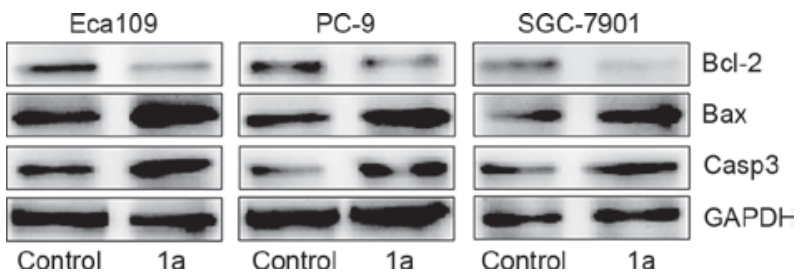

Figure 5. Western blot analysis of expression levels of the Bax, Bcl-2 and Casp3 protein on cancer cells following treatment with compound 1a. Bcl-2, B-cell lymphoma-2; Bax, Bcl-2-associated X protein; Casp3, caspase-3.

apoptosis induced by TSCs in tumor cells, western blotting was performed to measure the expression of Bax, Bcl-2 and caspase-3. As shown in Fig. 5, the expression level of the apoptosis proteins was significantly different following treatment with 1a, which decreased the expression of the anti-apoptotic factor Bcl-2 and increased the expression of the pro-apoptotic factor Bax and caspase-3 ( $\mathrm{P}<0.05$, Student's t-test). These 
results may improve the understanding of the pharmacological mechanism of the compounds in the treatment of cancer.

\section{Discussion}

The five TSCs exhibited a concentration-dependent cytotoxic effect in the human tumor cell lines assessed in the present study. The $\mathrm{IC}_{50}$ values for $1 \mathrm{a}$ were significantly decreased compared with the other TSCs in all tested cells. The steric effect of N(4) substitutes in TSCs may explain the trends. 1a has a smaller sterical hindrancecompared with the other TSCs, which allows 1a to interact with biomolecules efficiently and is responsible for improved antitumor activity. Since the 1a isoform had more powerful anti-tumor effects, it was selected for the subsequent TUNEL staining and western blot analysis to clarify the possible involved mechanisms. Apoptosis, a program of cellular suicide, is a form of programmed cellular death that occurs through activation of the cell-intrinsic suicide machinery and is considered an important mechanism in the action of numerous anticancer drugs $(22,23)$. As shown in Fig. 4, the TUNEL assay confirmed that the number of apoptotic cells induced by la is increased compared with the other TSCs, which is consistent with the result of cytotoxic activities.

As previously reported, the $\mathrm{Bcl}-2$ family proteins are key regulators of the apoptotic pathway (24). When Bcl-2 is produced in excess, cells are protected from apoptosis. By contrast, when Bax expression is high, the cells proceed into apoptosis. It has been suggested that the alteration in the balance between Bcl-2 and Bax is critical to determine the susceptibility of cells to apoptosis (25). Caspases, a family of cysteine proteases, are the central regulators of apoptosis. Caspase-3 is the main downstream effector caspase that performs essential roles in degrading the majority of key cellular components in apoptotic cells $(26,27)$. In the present study, western blot analysis was performed to determine whether Bax/Bcl-2 and caspase-3 were involved in the process of apoptosis induced by $1 \mathrm{a}$ in the three human cancer cell lines. Concomitantly, 1a significantly induced cancer cell apoptosis accompanied by increasing the expression of $\mathrm{Bax} / \mathrm{Bcl}-2$ ratio and activation of caspase-3.

Overall, the present study suggests that TSCs bearing pyrrole units possess the potential for development as novel agents for human cancer therapy. Additional experiments are required to explore the effects and potential mechanisms of such TSCs in vivo. As predicted, the present study demonstrated that such compounds show considerable antitumor activity against three human-derived cancer model cell lines, namely the human lung cancer PC-9, human esophageal cancer Eca-109 and human gastric cancer SGC-7901 cell lines. In addition, complex TSC 1a significantly induced cancer cell apoptosis, accompanied by increased $\mathrm{Bax} / \mathrm{Bcl}-2$ ratio and activation of caspase-3. In conclusion, TSCs bearing pyrrole units possess the potential for development as novel agents for human cancer therapy.

\section{Acknowledgements}

This study was supported in part by the National Natural Science Foundation of China (grant no. 81201908, 21404033),
Fund of the Natural Science Foundation of Jiangsu (grant no. BK20141122), and Development Fund of Clinical Science and Technology of Jiangsu University (grant no. JLY20140065).

\section{References}

1. Huang $\mathrm{H}$, Chen $\mathrm{Q}, \mathrm{Ku} \mathrm{X}$, Meng L, Lin L, Wang X, Zhu C, Wang Y, Chen Z, Li M, et al: A series of alpha-heterocyclic carboxaldehyde thiosemicarbazones inhibit topoisomerase IIalpha catalytic activity. J Med Chem 53: 3048-3064, 2010

2. Jansson PJ, Sharpe PC, Bernhardt PV and Richardson DR Novel thiosemicarbazones of the ApT and DpT series and their copper complexes: Identification of pronounced redox activity and characterization of their antitumor activity. J Med Chem 53: 5759-5769, 2010.

3. Soares MA, Lessa JA, Mendes IC, Da Silva JG, Dos Santos RG, Salum LB, Daghestani H, Andricopulo AD, Day BW, Vogt A, et al: N(4)-Phenyl-substituted 2-acetylpyridine thiosemicarbazones: Cytotoxicity against human tumor cells, structure-activity relationship studies and investigation on the mechanism of action. Bioorg Med Chem 20: 3396-3409, 2012.

4. Enyedy ÉA, Primik MF, Kowol CR, Arion VB, Kiss T and Keppler BK: Interaction of Triapine and related thiosemicarbazones with iron (III)/(II) and gallium (III): A comparative solution equilibrium study. Dalton Trans 40: 5895-5905, 2011.

5. Kowol CR, Trondl R, Arion VB, Jakupec MA, Lichtscheidl I and Keppler BK: Fluorescence properties and cellular distribution of the investigational anticancer drug triapine (3-aminopyridine-2-carboxaldehyde thiosemicarbazone) and its zinc (II) complex. Dalton Trans 39: 704-706, 2010.

6. Zeglis BM, Divilov V and Lewis JS: Role of metalation in the topoisomerase II $\alpha$ inhibition and antiproliferation activity of a series of $\alpha$-heterocyclic-N4-substituted thiosemicarbazones and their Cu (II) complexes. J Med Chem 54: 2391-2398, 2011.

7. Ramachandran E, Thomas SP, Poornima P, Kalaivani P, Prabhakaran R, Padma VV and Natarajan K: Evaluation of DNA binding, antioxidant and cytotoxic activity of mononuclear Co (III) complexes of 2-oxo-1,2-dihydrobenzo [h] quinoline-3-carbaldehyde thiosemicarbazones. Eur J Med Chem 50: 405-415, 2012.

8. Raja DS, Paramaguru G, Bhuvanesh NS, Reibenspies JH, Renganathan R and Natarajan K: Effect of terminal N-substitution in 2-oxo-1,2-dihydroquinoline-3-carbaldehyde thiosemicarbazones on the mode of coordination, structure, interaction with protein, radical scavenging and cytotoxic activity of copper (II) complexes. Dalton Trans 40: 4548-4559, 2011.

9. Li MX, Zhang LZ, Yang M, Niu JY and Zhou J: Synthesis, crystal structures, in vitro biological evaluation of zinc (II) and bismuth (III) complexes of 2-acetylpyrazine N(4)-phenylthiosemicarbazone. Bioorg Med Chem Lett 22: 2418-2423, 2012.

10. Li MX, Zhang LZ, Zhang D, Ji BS and Zhao JW: Synthesis, crystal structures, and biological evaluation of manganese (II) and nickel (II) complexes of 4-cyclohexyl-1-(1-(pyrazin-2-yl) ethylidene)thiosemicarbazide. Eur J Med Chem 46: 4383-4390, 2011.

11. Li MX, Zhang D, Zhang LZ and Niu JY: Synthesis, crystal structures, and biological activities of 2-thiophene N(4)-methylthiosemicarbazone and its unusual hexanuclear silver(I) cluster. Inorg Chem Commun 13: 1268-1271, 2010.

12. Matesanz AI, Leitao I and Souza P: Palladium (II) and platinum (II) bis (thiosemicarbazone) complexes of the 2,6-diacetylpyridine series with high cytotoxic activity in cisplatin resistant A2780cisR tumor cells and reduced toxicity. J Inorg Biochem 125: 26-31, 2013.

13. Matesanz AI and Souza P: Unprecedented Pt(II) complex of an asymmetric 2,6-diacetylpyridine bis $\left({ }^{4} \mathrm{~N}\right.$-substituted thiosemicarbazone) ligand. Inorg Chem Commun 27: 5-8, 2013.

14. Palanimuthu D, Shinde SV, Somasundaram K and Samuelson AG: In vitro and in vivo anticancer activity of copper bis (thiosemicarbazone) complexes. J Med Chem 56: 722-734, 2013.

15. Ilies DC, Pahontu E, Shova S, Gulea A and Rosu T: Synthesis, characterization and crystal structures of nickel(II), palladium(II) and copper(II) complexes with 2-furaldehyde-4-phenylthiosemicarbazone. Polyhedron 51: 307-315, 2013.

16. Vine KL, Matesic L, Locke JM, Ranson M and Skropeta D: Cytotoxic and anticancer activities of isatin and its derivatives: A comprehensive review from 2000-2008. Anticancer Agents Med Chem 9: 397-414, 2009. 
17. Ye XP, Zhu TF, Wu WN, Ma TL, Zhang ZP, Wang Y and Jia L: Syntheses, characterizations and biological activities of two $\mathrm{Cu}(\mathrm{II})$ complexes with acylhydrazone ligand bearing pyrrole unit. Inorg Chem Commun 47: 60-62, 2014.

18. Wang Y, Yang ZY and Chen ZN: Synthesis, characterization and DNA-binding properties of four $\mathrm{Zn}$ (II) complexes with bis (pyrrol-2-yl-methyleneamine) ligands. Bioorg Med Chem Lett 18: 298-303, 2008.

19. Sheldrick GM: SADABS, program for empirical absorption correction of area detector data. University of Göttingen, Germany, 1996.

20. Sheldrick GM: SHELX-97, program for crystal structure solution and refinement. University of Göttingen, Germany, 1997.

21. Yang M, Lu YL, Li MX, Xu XW and Chen L: Synthesis, crysta structures and biological evaluation of 2-benzoylpyridine $\mathrm{N}(4)$-cyclohexylthiosemicarbazone and its binuclear copper(II) complex. Inorg Chem Commun 35: 117-121, 2013.

22. Nouri K and Yazdanparast R: Proliferation inhibition, cell cycle arrest and apoptosis induced in HL-60 cells by a natural diterpene ester from Daphne mucronata. Daru 19: 145-153, 2011
23. Farnebo M, Bykov VJ and Wiman KG: The p53 tumor suppressor: A master regulator of diverse cellular processes and therapeutic target in cancer. Biochem Biophys Res Commun 396: 85-89, 2010.

24. Shu D, Qing Y, Tong Q, He Y, Xing Z, Zhao Y, Li Y, Wei Y, Huang $\mathrm{W}$ and $\mathrm{Wu} \mathrm{X}$ : Deltonin isolated from Dioscorea zingiberensis inhibits cancer cell growth through inducing mitochondrial apoptosis and suppressing Akt and mitogen activated protein kinase signals. Biol Pharm Bull 34: 1231-1239, 2011.

25. Cory S and Adams JM: The Bcl2 family: Regulators of the cellular life-or-death switch. Nat Rev Cancer 2: 647-656, 2002.

26. Nagaraj NS, Anilakumar KR and Singh OV: Diallyl disulfide causes caspase-dependent apoptosis in human cancer cells through a Bax-triggered mitochondrial pathway. J Nutr Biochem 21: 405-412, 2010.

27. Han YH, Kim SZ, Kim SH and Park WH: Pyrogallol inhibits the growth of lung cancer Calu-6 cells via caspase-dependent apoptosis. Chem Biol Interact 177: 107-114, 2009. 